\title{
Beyond National Models?
}

Governing migration and integration at the regional and local levels in Canada and Germany

\section{Oliver Schmidtke}

\author{
CMS 1 (1):77-99 \\ DOI: $10.5117 / C M S 2014.1 . S C H M$
}

\begin{abstract}
This comparison of Canada and Germany focuses on a particular dimension of these countries' respective approaches to governing migration and integration. It is guided by a key conceptual assumption: Cities and regions have become important laboratories for deliberating, developing, and implementing immigration and, in particular, integration policies. With this analytical lens, the article investigates the form and degree to which subnational levels of government have come to play a more prominent role in this policy field. Both Canada and Germany show a comparable diffusion of governance authority across different levels of government. Yet the factors driving this development vary considerably across national contexts. While Canada's multicultural policy has set a comprehensive national framework for addressing the task of migrant integration, in Germany the momentum in this policy field has moved decisively to regions and cities.
\end{abstract}

Keywords: migration, integration, regions, municipalities, multi-level governance, Canada, Germany

\section{Introduction}

When it comes to governing migration, Canada and Germany seem to constitute fundamentally different national contexts: On the one side of the Atlantic, Canada represents for many the ideal "settler society," whose sense of collective identity is constituted by the widely shared experience 
of migration. More than forty years of endorsing cultural diversity under the auspices of the public policy of multiculturalism has arguably moved Canada decisively away from the legacy of social exclusion of newcomers that (still) plagues many European nation states. On the other side of the Atlantic, until the turn of the century, Germany relied on a primordially defined notion of citizenship and defined itself categorically as not being a "country of immigration" (Green 2000). A coherent integration policy is still in its infancy and, according to a recent statement by Chancellor Angela Merkel, multiculturalism has "utterly failed" in Germany.

At first glance, assessing both countries in a comparative study might demand the evaluation of rather lopsided bodies of information - from the "champion of multiculturalism" and a country still struggling to find an effective approach to governing migration and integration. Yet, such simple categorization of both countries would be misleading in two essential ways: First, the concept of Canada as a "champion of multiculturalism" would be historically inaccurate. Canada's approach to governing migration was originally rooted in a genuinely European legacy of nation-building. Only gradually has Canada separated its immigration policies from any notion of an ethnically rooted national identity and simultaneously developed an ethos of diversity, fundamentally opposed to the exclusive concept of nationhood cultivated in the European tradition. ${ }^{2}$ Second, the argument that we are confronted with profoundly different national contexts is based on an important, yet increasingly doubtful supposition: that it is appropriate to refer to distinct and homogenous national models when it comes to regulating migration and diversity. In this respect, any misgivings regarding the feasibility of a trans-Atlantic comparative study are due in part to a more general tendency in the field of migration research: a disproportionate focus on national models of integration and accommodation of diversity (Entzinger \& Biezeveld 2003; Parekh 2006).

By looking at how issues of migration and integration are addressed in systems of multi-level governance, I will develop a more comprehensive comparison between Canada and Germany. To do this, I focus on the empowerment of the subnational level: In both countries we see a momentous decentralizing shift in governing migration and integration manifesting the broader downloading of public policy responsibilities from the federal to regional or local governments. First, I briefly develop the analytical perspective for this transatlantic comparison and argue in favor of a more nuanced interpretation of how issues of migration and integration are addressed in the two national contexts under investigation. Second, in the main part of the empirical analysis, attention shifts to the factors that have promoted 
decentralizing trends in governing migration in both countries. Third, in the concluding section, I interpret the findings with respect to the markedly different dynamics that have driven the empowerment of the subnational level of governance in Canada and Germany.

\section{An analytical perspective beyond national models}

An empirical observation that has considerable analytical implications informs this comparative perspective on immigration and integration in Canada and Germany. Traditionally migration research has widely been driven by a methodical approach almost exclusively focused on national models (suffering from the fallacies endemic to what Wimmer and GlickSchiller 2003 have termed 'methodological nationalism'). Yet, there is mounting empirical evidence of a growing heterogeneity of immigration and integration policies, not only across but within nation-states (Baraulina 2007). An emerging literature points to how regional and municipal outcomes differ significantly from national ones (Caponio \& Borkert 2010; Poppelaars \& Scholten 2008; Scholten 2013). With respect to integration policies at the national and local levels in the Netherlands, Poppelaars and Scholten (2008) speak about distinctly "divergent logics of national and local integration policies." In a similar vein, Duyvendak and Scholten (2011) show how scholarly and political discourse popularizes notions of coherent national models that are characterized empirically by a much greater internal diversity in policy formation and program development (see also Bertossi \& Duyvendak 2012).

The sub-national level of governance has become a meaningful arena of political debate and policy formation in the field of integration policy. Thus, we need to move beyond a conceptualization that is restricted to national politics, its institutional arrangements and its actors. It is both conceptually misleading and factually incorrect to speak of a single - national - model responsible for the formation of immigration and integration policies. Rather, from a broader governance perspective, regions and cities have become important laboratories for deliberating, developing and implementing integration policies (Vasta 2007). As such, they have become significant sites of innovation in the European context often in open contrast to the lack of coherent policy formation at the national level (Schmidtke \& Zaslove 2014b). The field of integrating newcomers into the fabric of society is particularly conducive to the growing emphasis on place, and community-based governance approaches and social policy development (Bradford 2005). In this 
respect, the emergence of municipalities and regions as significant policy innovators in governing migration and integration denotes a more general trend specific to this arena of public policy making.

The methodological implications of such claims are substantial: While it is manifest that there are important institutional, political and cultural structures characterizing national contexts in systems of multi-level governance, it becomes imperative to conceptualize the subnational level as constitutive of public policy formation and the practice of migrant integration. Primarily due to the formative role of national identities migration studies have relied in a particularly persistent way on the nation state as the exclusively frame of reference for comparative analyses (Wimmer 2008). In the following empirical study, I investigate how the increasingly significant subnational level of governance in Canada and Germany has challenged the traditional notion of 'national models' and how the decentralizing trend in managing migration plays out in both countries.

\section{Governing migration and integration from below: empowering the subnational level in Canada and Germany}

As federal states, Canada and Germany are both shaped by the legacy of the constitutionally mandated division of authority between the federal and provincial/ Länder level. This division of authority has had a significant impact on how immigration policies have evolved in both countries. In this empirical section, three dimensions of a gradual empowerment of the subnational level of governance will be explored: 1) the increasingly important role of regions and cities in addressing issues of migration and integration in policy terms; 2) the subnational context as an arena for civil society engagement and place-based approaches to integration; and 3) the impact of the emerging European system of multi-level governance.

\subsection{Regions and cities as part of a comprehensive migration regime}

The political regulation of migration and integration is an intricate and at times controversial feature of Canada's federal system. Over the past twenty years there has been a persistent trend toward decentralizing policy and administrative competences in Canada's immigration and integration regime. While the federal government still holds the prime authority over recruiting migrants, the provision of services to newcomers and efforts to 
integrate them into the fabric of society have been transferred decisively to the sub-national level of governance.

Two developments within the framework of federal-provincial relations are of critical importance when it comes to governing migration and integration: first, the transfer of authority over settlement services and integration programs to provincial and municipal governments, and second, the introduction of provincial migrant recruitment schemes that have allowed provinces to complement federal schemes of attracting newcomers. This decentralization trend and devolution of policy authority does not affect all subnational levels of governance equally; still the last two decades have seen a substantial shift toward provincial and municipal levels.

Since the 1990s, Canada has undergone a fundamental restructuring of the way that settlement services for newcomers are organized. Leo and August (2009) speak of "deep federalism" at work in the governance of migration and settlement, indicating how profound the transformation has been. Although there has been considerable variation in the degree to which provinces negotiated agreements with the federal government, provinces and municipalities have been empowered to take on the task of migrant integration by expanded funding schemes and greater degrees autonomy in program development (for a comparison of different provinces see: Biles 2008; Seidle 2010).

As Hiebert and Sherrell (2009) argue in their study of the settlement industry in BC, the task of integrating newcomers to Canada has undergone a process of decentralization whereby responsibility has been handed down to the regional and local levels. Following a neoliberal logic in the new management tradition, this policy field has been transformed by the federal and provincial governments' attempts to outsource responsibility for settlement services to community organizations, harness the involvement of community groups, and seek greater efficiency in the use of public resources. These changes have been coupled with an increase in provincial funding thereby creating new opportunities for the development of multicultural policies and integration programs.

The key component in empowering the sub-national level of government is the Provincial Nominee Program (PNP). The development of provincial and territorial nominee programs represents a change in Canada's nearly century-old immigration practice under which the selection and admission of immigrants (except for those in Quebec) have been exercised almost exclusively through the federal immigration program. The Canadian Constitution (section 95) recognizes this multi-level approach by proclaiming immigration a matter of shared federal and provincial jurisdiction and 
by institutionalizing a federal-provincial consultation process regarding the management of immigration. As of 2007 the federal government has signed agreements with eight provinces and one territory to facilitate the coordination and implementation of immigration policies and programs.

First introduced in Manitoba in 1998 (Carter \& Amoyaw 2011), the PNP has since expanded to include all provinces and territories, except Nunavut and Quebec, which have their own economic class selection systems. In 2002 , only 1.5 percent of all economic-stream migrants were provincial nominees, but this figure jumped to 15 percent in 2008. These programs are designed to allow provincial and territorial governments to operate their own immigrant selection systems. Under this scheme, migrants are nominated by a province; the nomination is based on the migrant's skills, language abilities, education, and Canadian work experience, with a view to an immediate fit with the labour market needs of the respective province. The PNP has effectively ended the federal monopoly over migrant recruitment; it has empowered provinces - notwithstanding the fact that the degree of autonomy over the selection varies substantially from province to province - to use migration as a policy tool for their economic development plans.

Depicting the devolution of authority over managing immigration in such generalized terms it is important to realize that this trend has not materialized uniformly across the country. In this respect, Reese (2011) accurately refers to an exceptional asymmetry in Canada's multi-level immigration and integration policy. The 1991 Canada-Quebec Accord that essentially handed over exclusive responsibility for governing immigration and integration to Quebec has not served as a blueprint for empowering other provinces. Rather, across the country provinces are faced with different (and to certain degree incoherent) arrangements of shared federal-provincial jurisdiction in this policy field. In addition, as Li (2012: 106) shows in his detailed study, provinces use the PNP for different socio-economic purposes creating a 'multi-tiered system of immigrant selection'. This development threatens to undermine Canada's immigrant recruitment system operating on stringent expectation regarding qualifications and professional expertise (provincial recruitment standards being considerably lower than federal ones).

\section{Cities and integration: The "sleeping giant"}

Next to the provinces, cities have emerged as sites in which the challenge of integrating newcomers is most pronounced. Canada's main metropolitan areas have become environments of what Steven Vertovec (2006) describes as "superdiversity," where the very notion of identifying minorities and 
majorities becomes questionable. In cities like Toronto, Vancouver, and Montreal, "visible minorities" are predicted to become the majority of the population by 2017 (Belanger 2005). This fast-changing demographic reality has pushed city authorities to consider developing a more active, locally based approach to governing migration and diversity (see: Frideres 2006; Polese \& Stren 2000; Seidle 2010; Siemiatycki 2011; Stasiulis, Hughes \& Amery 2011). Still, in spite of widely shared challenges, particularly among Canada's urban population - challenges linked to growing ethno-cultural diversity - there is a significant variation in municipal responsiveness to the issue (Good 2005).

Given the limited fiscal resources and municipal authorities' informal status in the settlement and integration policy process, so far city governments have remained on the margins of this policy field. ${ }^{3}$ Biles et al. (2011) use the term "sleeping giant" when they consider the centrality of the municipal leadership in the task of integrating newcomers and the relative absence of municipal government from this field of public policy thus far. Until recently, there has been a manifest disconnect between the recognition that, as it was put in the tradition of the Chicago School, cities are the primary 'machine of integration' and a reluctance to provide them with the authority and funding to play a leading role in this policy field. Furthermore, Biles and his colleagues have analyzed changes in the provision of migration and integration policy in Ontario over the past decade, in which a policy area that had long been dominated by the federal government was transformed into a complex multipartite process involving both provincial and municipal levels of government. Reflecting on the exceptionally innovative policy responses of urban centres like Winnipeg, Calgary, and Toronto, Biles (2008) notes how cities have come to play a more active role in the integration process (see also the comprehensive study by the Maytree Foundation, 2013). In his analysis, this development is rooted in the simple fact that new immigrants tend to settle and require services in metropolitan areas ${ }^{4}$. What Biles sees with respect to migrant integration is how the urban context constitutes not only the immediate environment in which the settlement of newcomers is addressed but also the site for facilitating partnerships and modes of cooperation between government agencies and civil society groups (Biles 2008: 163-66). Analyzing Ontario's emergent multipartite immigration and settlement policy framework, Stasiulis, Hughes, and Amery (2011: 74) make a similar assessment: they find this policy framework emblematic of "a discernible movement in Ontario's immigrant-receiving centres from government to multilevel, multisectoral governance in the policy area of immigrant settlement." 
Sensitivity to the specific challenges and opportunities in the community is also at the heart of delivering effective settlement and integration services in Canada. In a multi-city study, Tossutti (2012) looks at what kind of normative-conceptual ideas inform practices in urban centres. He finds a considerable degree of variation across the cases and significant deviations from Canada's state-level policy of multiculturalism. Decentralizing services and then relying on local alliances to deliver these services involves compromise in terms of the comprehensive recognition of cultural diversity and centralized strategies to address it. Currently, Canada seems to lack adequate coordinating initiatives and has not implemented appropriate collective learning processes. The result is - as Tossutti shows in his study - that approaches to accommodating diversity in the Greater Toronto Area, for example, are likely to look very different from such approaches in, say, Edmonton or Brampton. In the same vein, Tolley (2011) points to how recent legislative initiatives in immigrant settlement policy have set the stage for a "multilevel but somewhat 'silo-like' approach" (8). Thus, the diffusion of authority to lower levels of governance has led to both innovative, placesensitive policy development and the deterioration of some of the ambitious claims associated with key multicultural principles (see Siemiatycki 2012).

These factors point to a persistent trend toward decentralizing authority over migration and integration by empowering provinces and cities. Yet, at the same time, there are limits to the federal government's willingness to see its prerogative in this policy field challenged. One critical issue is the constraint under which the sub-national levels of government must pursue their initiatives given their limited jurisdictional and fiscal powers. In this respect, this shift in policy authority could also be characterized as the federal government downloading responsibility onto provincial and municipal authorities without providing them with adequate funding to take on these new mandates.

Contrary to this decentralizing trend the Conservative government under the leadership of Prime Minister Stephen Harper has recently announced that the federal government will begin to reduce provincial authority in migration and settlement policy (the expansion of the Canada Experience Class Program is one example of strengthening federal authorities). One of the driving forces behind this reversal - re-instating federal authority over settlement programs and scaling back the PNPs - is the push by provinces such as Ontario to have similar privileges as other provinces. 


\subsection{Place-based approaches to integration and civil society engagement}

Friction between the federal government and regional or local approaches to integration are more pronounced in Germany than in Canada. This has to do with, primarily, the political environment in which issues of migration and integration are addressed in the German (or, more broadly, European) context. In recent years, issues of integration have become central in what is at times a fiercely controversial debate about how and to what extent issues of religious and ethno-cultural difference should be addressed (Bauder 2008). In the post-9/11 world, this public discourse - reproduced by important parts of the political elite - has shifted decisively toward a top-down approach to security and the view that multiculturalism is a threat to the integrity of society. In the wake of the "backlash against multiculturalism" (Vertovec \& Wessendorf 2010), integration policies have moved away from a public endorsement of cultural diversity and migrants' entitlements toward a stronger emphasis on state-monitored processes of integration (Joppke 2007; Triadafilopoulos 2011) or the "return of assimilation" (Brubaker 2001). Persistent emphasis on security issues and concerns about the - allegedly menacing - challenges posed by cultural and religious diversity has prevented a comprehensive integration policy from taking shape. This lacuna has created new opportunities for sub-national levels of governance to establish themselves as significant actors, both with respect to the direction of the national debate on migration and in terms of policy developments in the field.

In an empirical study of the German Land (term for region in the German federal system) of North-Rhine Westphalia (see for detailed findings: Schmidtke \& Zaslove 2014a, 2014b), we detected a distinct logic of deliberating and framing the issue of migration integration at the regional level. Conducting a frame analysis of elite discourse we found a predominantly pragmatic deliberation of migration issues across party lines. In stark contrast to the highly divisive national debate about alleged threats associated with cultural and religious diversity, the integration discussion in this region is framed in terms of the region's interests and the need to provide migrants with equitable opportunities in the educational sector and the labour market. The logic of politicizing issues of migration and diversity and the move away from an overly dramatic discourse about threats toward a pragmatic, interest-driven discussion create significant opportunities for innovative policy development at the sub-national level.

Second, Germany's national Integration Plan, launched in 2007, is designed to shift competence and responsibilities to regions and cities. 
Both municipal and regional authorities were invited to join in a partnership with the federal government to address the policy issues of migration and diversity. ${ }^{5}$ With the national Integration Plan, the federal government acknowledged a trend that had developed over the previous ten to fifteen years, during which local and regional governments had been more and more active in fostering initiatives targeted at migrants. The tendency on the part of the federal government to give more power to these regions in addressing migration-related issues also results from the nature of German federalism. In particular, integration policy improvements have been directly linked to wider concerns with the German educational system and the labour market - policy areas that are shared between central and state governments. Accordingly, with integration posing challenges for policy domains with a shared regional-federal competence, the sub-national level has gained considerable flexibility in defining integration on the ground and in developing its own policy approaches.

North-Rhine Westphalia (NRW) has been a pioneer in promoting its own integration policy and program development. A proactive approach in this field was developed under social-democratic rule before 2005 and continued under the Christian Democratic Prime Minister Jürgen Rüttgers (Korte 2009). NRW has actively taken advantage of the gradual empowerment of the regional and local levels of governance within the German federal state structure with regards to integration policy (The 2004 Immigration Law-Zuwanderungsgesetz - allows for a new form of collaboration between the federal and regional levels on integration matters, as well as providing a framework for new funding opportunities for regional and local authorities in this policy area.). Immigrant integration became a central political objective pursued by NRW's Ministry for Intergenerational Affairs, Family, Women and Integration. In this respect, NRW has been a trendsetter: similar ministries have been introduced in other, often CDU-governed, states (Lower Saxony, Hesse, Schleswig Holstein, and Berlin). NRW has also spearheaded the idea of a conference for integration ministers at the state level. It is remarkable how the CDU-led government and its integration minister, Armin Laschet, were able to address the challenge of incorporating migrants into regional society through a pragmatic policy approach - in stark contrast to the highly controversial and emotional debate in the national political arena.

Under both a centre-left and a centre-right administration, NRW has developed innovative approaches to promoting integration designed to attract and retain newcomers (one prominent example is a comprehensive language training program for pre-school children). The major thrust of 
the legislative initiatives in this field is directed toward (equitable) access to the labour market and educational opportunities. It is indicative of the overall orientation of NRW's integration policies that the state secretary for integration has traditionally been incorporated into the Ministry for Labour and Social Affairs. In legislative terms, the 2001 Integrationsoffensive Nordrhein-Westfalen (Integration Offensive NRW) set the agenda for a comprehensive strategy for promoting the integration of newcomers, an initiative that in its design and scope was unique in Germany. The plan outlines how successful integration must involve all sectors of society (from the labour market and the educational sector to urban planning, civil society organizations, and the business community) and needs to be driven by concerns for equal opportunities (Chancengleichheit). There are no robust data available measuring the success and effectiveness of integration measures in NRW (relative to other Länder). Yet, the Ministry has started to measure the impact of its programs with regard to some key indicators focusing primarily on migrants' achievement in the labour market and educational institutions ${ }^{6}$. The results since micro census data on migration status became available in the mid-20oos are - in spite of the economic downturn - pointing toward more opportunities for migrants.

In 2011, the new Red-Green government in Düsseldorf and its current integration minister Guntram Schneider have begun the process of launching a new Teilhabe-und Integrationsgesetz (Participation and Integration Law), the goal of which is to create binding legal entitlements for immigrants. NRW is the first region to embark on such an ambitious legislative initiative, which could set the agenda for governments at various levels in Germany's federal system. While the region might be an outlier within the German context in terms of its legacy of social-democratic rule, its promotion of a regionally and locally specific approach to integration is indicative of the more structural origins of effective policy making in the German polity. At least partly due to innovative approaches in NRW, other regional governments and ministries needed to react with their own initiatives. What has evolved is a cycle of positive incentives and mutual learning at the subnational level of governance - at times, however, against the notable resistance from some of the Länder (most notably in the conference of integration ministers). In this respect, the sub-national level of governance - in partnership with the federal government - has become a policy entrepreneur, with its own pragmatic framing and resulting policy priorities. 


\section{Civil society empowerment and immigrant integration}

State-centred multicultural policies have set in motion a dynamic that has far exceeded the expectations of the federal government. Yet, the Canadian multicultural project could not have been as successful as it has had it been undertaken solely with a state-centred, top-down approach. In recent decades, various civil society groups have increasingly played a role in defining the nature and limits of group-specific rights. In this respect, "multiculturalism" has become a kind of political umbrella under which civil rights activists, immigrant and minority advocacy groups, union organizations, political parties and business groups have engaged in determining how the abstract principles of fostering cultural diversity will play out on the ground (Falge, Ruzza \& Schmidtke 2012). Particularly in the Canadian context, it is striking to see how advocacy groups representing different migrant communities have become an articulate and influential voice in the public arena. This voice is remarkably shaping political agendas in a far more sophisticated way than in a typical European context, where this type of vocal migrant advocacy is still in its infancy. Issues of migration and related questions of identity and equal inclusion have developed into an important political cleavage in contemporary Canadian society. These cleavages are most strongly articulated in urban governance settings.

The federal policy on multiculturalism has clearly had an impact on the mobilization of ethno-cultural communities. Particularly in the period after the 1970 s and 198 os, federal multiculturalism policy was intended to increase the capacity of immigrant communities to take collective responsibility for dealing with the causes of inequality and for developing mobilization strategies, including judicial recourse, in order for immigrants to be able to exercise their rights at all levels of government (Bradford 2005). The activity of civil society groups has contributed critically to making diversity and cultural pluralism principal issues in public debate and, from a normative perspective, principles endorsed in Canadian society and politics. In this regard, multiculturalism no longer simply celebrated folkloristic differences but evolved to also address matters of power sharing and some of the deep political cleavages in Canadian society. In sum, we can observe in the Canadian context a somewhat self-reinforcing cycle of ethnic mobilization and political responsiveness within the political system - a cycle driven by civil society organizations in urban contexts.

This dynamic is also structurally sustained by the previously discussed "outsourcing" of settlement services to community organizations. Beyond simply attending to these tasks as administrative agencies, civil society organizations have also taken on the role of political advocate for migrants, 
minorities, and influential agents in developing integration programs on the ground. The formation of integration policies at the local level is driven by a broader governance network, of which migrants' and minorities' organized interests have become a constitutive part. As Ley observes:

Bringing mainstream civil society closer to immigrant everyday life, these programs are delivered not by bureaucrats but by nongovernmental organizations (NGOs) with co-ethnic staff, and provide not only services but also jobs and volunteer positions to recent arrivals. The intent here is to create bridging social capital with immigrant groups through their NGOs and thereby aid the integration process (Ley 2007: 186).

At the same time, this community-based engagement unfolds in particular institutional and political-discursive contexts. It is worth highlighting that there are considerable differences in this respect between big urban centres, with well-organized migrant organizations, and smaller cities. In the latter, the task of representing these groups' interests and acting as agents of political advocacy is shaped by the prominence of a limited number of settlement agencies and the relative absence or weakness of smaller ethno-cultural community groups. Traditionally, political advocacy and (at least partial) access to the decision-making process in policy formation was afforded those organizations that provided settlement services in the community.

The German context provides further evidence for the critical role of the subnational and urban context for providing a space for effective political advocacy and inclusion: While conducting a policy process oriented toward pragmatic socio-economic priorities, state agencies in NRW have also been actively involved in nurturing the political engagement and participation of migrants themselves and their organizational bodies. At this level of government, commitment to political participation is geared toward grassroots involvement. Similarly, the inclusion of migrants in the political life and institutions of NRW has recently become more robust (Schönwälder 2013; Schönwälder \& Kofri 2010). State agencies in this Land have been involved in nurturing an infrastructure - partly through the use of material incentives - to support the self-organization of migrants in their communities. For instance, throughout the state, so-called "integration agencies" (126 in total) have been created to provide basic services to newcomers. These agencies play a dual role as service providers and as an institutional context for collective decision-making and political advocacy. In a similar vein, a project at the regional level called MigrantInnenselbsthilfe (migrant self-support groups) assists migrant organizations with conceptual, legal, economic, 
and financial issues, and in the area of public relations. In nurturing grass root engagement policy makers could rely on a well-developed network of civil society actors: organizations such as unions or church-based groups (for instance Caritas or Arbeiterwohlfahrt) had provided basic support for migrant integration long before this became slowly a policy priority in Germany in the 1990s (as in other countries cities and local actors have historically been the main promoters of migrant integration). These organizations have recently played a critical role in re-invigorating a bottom-up, place-sensitive approach to facilitating integration.

Comparing the regional to the national contexts, it is striking that in NRW the commitment to the political inclusion and participation of migrants has become key to this political practice in a substantive way. A number of migrant organizations and migrant representatives have been included in the policy process (at least in a consultative capacity). Local governance in particular is entrusted with promoting community partnerships, soliciting input from various civil society actors, and overseeing the implementation of new policies. This contrasts with the high-profile (albeit procedurally limited and contested) experience of the integration summits regularly organized by the federal government. Various institutional supports have also been created to further encourage political participation among migrants: In municipalities with more than 5,000 officially registered foreigners, it is mandatory to establish so-called integration councils (For instance, in February 2010, almost 100 of these integration councils were elected throughout NRW.). While these councils have only a limited, consultative role, they are still an important institutional vehicle for including migrants in the policy formation process. In addition, NRW has a rich history of civil society organizations that articulate the interests and concerns of migrants. ${ }^{7}$ The inclusion of migrants and their organizations in processes of community outreach and policy deliberation is an explicit goal of NRW's integration plans.

Evidence from comparative trans-Atlantic studies suggests a strong link between the degree of migrant participation and the facilitation of innovative program development. Falge, Ruzza, and Schmidtke (2012) found an array of formal and informal modes of including migrants and their organizations in the political process. Even though it is difficult to stipulate what kind of impact migrant organizations have on this field of public policy, local and regional-level authorities have generated some marked opportunities for community input and initiatives. Indeed, in the case study of NRW there was a direct link between the pragmatic orientation and breadth of integration initiatives and the way in which community organizations have 
become more firmly embedded in institutional practices and accepted by the wider policy community. Even though the formal inclusion of migrants and migrant organizations in the decision-making process in the policy community is rather limited, they are regularly brought into the political process, mainly in the form of community-based networks and consultative bodies. In this respect, a critical feature of the regional and local levels of governance is that they allow a greater degree of immigrant participation in public debates and thus encourage a different logic of societal and political incorporation. In their study on migration and development policies Hilber and Baraulina (2012) speak about a new policy paradigm which, in terms of the implementation process, is characterized by features similar to those highlighted in this article: the diffusion of policy authority across different levels of government (federal, regional and municipal) and the shift toward a more meaningful inclusion of non-state actors in decision process than in the past.

\subsection{Europe as an enabling context for sub-national actors}

In Europe, the emerging system of multi-level governance ${ }^{8}$ has created new political opportunities for sub-national-level actors to become policy entrepreneurs rather than simply administrators of federal programs. The idea that governance in Europe is multi-layered, generating binding collective decisions beyond the exclusive authority of the nation-state, offers a valuable interpretative framework for the dynamic of this policy field in Germany. While the ambitious plan to move immigration and asylum into the first pillar under community competence has not materialized to the degree laid out in the Amsterdam Treaty, the EU has taken important legislative steps in these policy areas (including, for example, issuing directives on family reunification; returning illegal migrants; and instituting policy initiatives, such as the Blue Card, designed to attract highly skilled migrants to Europe) and has instituted important benchmarks for national integration policy making. ${ }^{9}$

It is in part due to this multi-layered European governance structures that regions and cities in Germany have successfully explored new avenues for program and policy development. There are two key opportunities: First, cities and Länder have been able to benefit from the programs developed by the European Union in its endeavour to play a more authoritative role in governing migration and integration. While limited in scope, these financial and organizational programs have proved to be instrumental for many local initiatives, administrations in municipalities, and civil society actors. Since the 199os the EU's initiatives on social exclusion and racism (e.g. XENOS 
projects) have provided non-state actors with a range of opportunities to become more active in the field of migrant integration. Second, related, but not limited to these funding schemes is the opportunity for international policy learning. The European Union has been instrumental in setting up research-driven networks of cities faced with the challenge of governing migration and diversity. Prominent research projects include "Multicultural Democracy and Immigrants Social Capital in Europe: Participation, Organisational Networks, and Public Policies at the Local Level" ${ }^{10}$ and the "Cities for Local Integration Policies" (CLIP) project. These networks link cities across national borders and provide fora for exchange. In sharing common experiences and best practices in the field of local integration, city representatives can benefit by an international experience of policy learning. The coordination of local integration efforts across national borders promotes a collective learning process whose empowering effects on local and regional authorities cannot be overstated.

With the European Union creating incentives and the nation-states handing down responsibility in this policy area, the sub-national level of governance has taken on an increasingly important role in initiating horizontal and vertical forms of policy coordination. European authorities have also initiated a dynamic policy-learning process across different levels of governance. This has critical effects: Most importantly, it grants legitimacy and authority to the efforts of sub-national levels of government, whose actions are now, potentially, indirectly sanctioned by the European Union and its principles with respect to the integration of third-country nationals. This in turn has created commanding expectations for "laggards," encouraging the development of more comprehensive initiatives in the field of integration. For instance, in the German context, Länder have become a driving force in promoting agendas for governing migration and integration at the federal level. They have taken on the role of pace-setters and primary agents of innovative policy development. While it could be argued that this dynamic is due primarily to domestic politics and divided policy competence within the German federal system, the EU also plays a critical role in assigning more authority to the efforts of sub-national governments. With EU's funding schemes and benchmarks for successful integration of third-country nationals, Brussels has created new political opportunities emanating from the supranational governance level.

Yet, a word of caution is in order when assessing the role of the EU in promoting immigrant integration on the ground. The EU provides opportunities for subnational actors to pursue such policy initiatives. However, it takes an entrepreneurial administration and a favorable fiscal-political 
climate to take advantage of these forms of support and cross-regional exchange. These contexts are extremely heterogeneous across the EU in terms of whether immigrant integration becomes a priority in public policy making and programs are effectively implemented. In addition the recent economic crisis has changed the overall climate for policy making in a way that in particular in Europe's southern periphery migration and integration policies have been compromised at all levels of governance (Koser 2010; Papademetriou \& Terrazas 2009).

\section{Conclusion}

In both Canada and Germany we have witnessed a substantial strengthening of place-based approaches to governing migration and integration at the regional and urban levels. Gradually, the site for developing new initiatives in this field of public policy has shifted from the federal to the sub-national level of governance. In general terms, this development has been driven by the need to respond to locally specific challenges in regulating migration and, under the auspices of a neoliberal reorganization of public policy, by the general downloading of responsibility to lower levels of governance and a more market-based management approach. At the same time this devolution of policy competence has created what Schönwälder (2013) calls 'uneven dynamics' in terms of how immigrant recruitment and integration services have been implemented on the ground: there is remarkable diversity of services provided across Canada and Germany with individual regions (NRW in the German case) and in particular metropolitan municipalities taking a lead while others do not assign priority to this public policy domain.

Yet, different factors drive this development in each country. In Canada, one of the decisive factors shaping the diffusion of policy authority has been the decentralization of the provision of settlement services to newcomers and the government's outsourcing of services to non-governmental organizations (NGOs). This in turn has contributed to the empowerment of civil society organizations, has strengthened political advocacy, and has shifted the balance toward a more localized approach to migrant integration. Nonetheless, while Canadian provinces and territories have been empowered by a decentralized recruitment practice (most prominently with the Provincial Nominee Program), the ability of cities to address challenges related to migration and diversity is constrained by their limited jurisdictional and fiscal powers. 
In Canada, provinces and cities are dependent on a federal government that has embarked on a course of rolling back some of the decentralization measures taken in the arena of public policy making over the past two decades. Driven by concerns of the federal government as being challenged in its policy prerogative and by the demands of some provinces to have similar privileges as those that negotiated the most far-reaching agreements on developing and providing settlement services in the past, Prime Minister Stephen Harper has recently announced the move to reinstate federal authority in this policy domain. To what degree this decision will reverse the decentralization of settlement services and the empowerment of sub-national government levels in this public policy field remains to be seen. Without doubt, the environment in which provinces and municipalities seek to become more proactive in tackling the challenge of migrant integration will become more challenging.

In Germany, the structural features supporting regions and cities in their political ambitions differ from those in Canada and, though they derive from a considerably less robust policy of integration, arguably have undergone a more dynamic (and possibly more sustainable) development in recent years. The deciding factor is the lack of a coordinated and comprehensive integration policy at the national level. While the federal government has set the framework for a more vigorous approach to integration (committing regional and local governments as key partners in the national Integration Plan), implementation of the strategies on the ground is still sketchy and politically contested in competitive party politics. Sub-national actors have filled this political void. Länder and municipalities have started to develop their own, space-sensitive, approaches to integration. The lack of national leadership and the pragmatic challenges on the ground have propelled the sub-national level of governance into the role of policy entrepreneurs. Furthermore, unlike in Canada where federal politics plays a dominant role in this policy domain, in Germany immigrants' political inclusion is primarily promoted at the regional and municipal level. An additional key factor in the German context is Europe's system of multi-level governance and the international support network that this has created. By providing funding opportunities, setting benchmarks for migrant integration, and empowering civil society actors at the sub-national level of governance, the European Union has - indirectly - been instrumental in challenging the national governments in their exclusive authority over this policy level. Of critical importance in this respect is the EU's granting of legitimacy and authority to regions and cities. 
Many cities in Canada have also developed ambitious programs to address challenges of integration. Yet, these initiatives often stay isolated: Canadian cities cannot rely on the sort of international collaboration and collective policy learning that has been established in the context of European integration. The decentralization of governing migration and integration might have started at a much lower level of policy development in Germany; currently, however, cities and regions are well on the path toward establishing themselves as vital governance arenas and policy entrepreneurs. It is an empirically open question to assess whether regions and municipalities will continue playing a pioneering role in promoting migrant integration. In the European context the polarized debate on immigration, populist-anti-immigrant actors in competitive party politics as well as the ramifications of the economic crisis are not likely to make this task any easier.

\section{Notes}

1. Seehttp://www.guardian.co.uk/world/2010/oct/17/angela-merkel-german-multiculturalismfailed (accessed October 2, 2013).

2. Two recent books have shed light on how instructive a Canadian-German comparative perspective promises to be if processes transforming both countries' migration policies and national identities are studied in a historic perspective (Bauder 2011; Triadafilopoulos 2012).

3. Canada's comprehensive 'settlement program' has traditionally been organized in form of a federal-provincial partnership. The current federal settlement budget of currently over $\$ 600$ million annually almost exclusively flows through the provinces that organize the services for immigrants on the ground. It is only over the past couple of years that more formal agreements with municipalities (mostly with limited responsibilities for housing and social services) have been established. Still the Federation of Canadian Municipalities has been adamant in its quest for a fuller inclusion of municipalities in the organization and funding of Canada's settlement services.

4. Similarly, the Federation of Canadian Municipalities (FCM 2011) highlights both the role of cities as the first point of contact and integration for newcomers to Canada and the challenges that Canadian cities face in fulfilling this important role, due to their limited fiscal resources and their informal status in the settlement and integration policy process. The report calls on the federal and provincial governments to create a formal role for municipalities, using the tripartite Canada-Ontario-Toronto Memorandum of Understanding on Settlement and Integration as a model.

5. The national Integration Plan states explicitly: "The immediate or residential environment has a key role to play in the integration process. This environment will decide on the success of integration in the everyday coexistence of people of different origins. Cities, counties and municipalities are aware of their crucial responsibility for integration." See http:// www.coe.int/t/dg4/youth/Source/Resources/Forum21/Issue_No10/N1o_National_integration_plan_en.pdf (accessed September 28, 2013) 
6. Available at: http://www.integrationsmonitoring.nrw.de/integrationsberichterstattung_nrw/Grundlagen/Messung_integration/index.php (accessed September 30, 2013)

7. Ilgün \& Jungk (2001) produced a list of 2,400 such migrant organizations in NRW.

8. The concept of multi-level governance has been developed as part of wider research on European integration (Hooghe \& Marks 2001). The central goal of this research is to enable a better understanding of fundamental changes in the locus of political authority provoked by the deepening of European integration. Challenging a state-centric perspective, the model assumes that decision-making competences are increasingly shared by actors at different levels rather than monopolized by actors in the national domain.

9. See Justice and Home Affairs: http://ec.europa.eu/justice_home/doc_centre/immigration/ doc_immigration_intro_en.htm (accessed September 19, 2013)

10. See http://www.um.es/localmultidem/index.php (accessed September 21, 2013).

\section{References}

Baraulina, T. (2007). Integration und Interkulturelle Konzepte in den Kommunen. Aus Politik und Zeitgeschichte, 22-23, 26-32.

Bauder, H. (2008). Media discourse and the new German Immigration Law. Journal of Ethnic and Migration Studies, 34 (1), 95-112.Bauder, H. (2011). Immigration Dialectic: Imagining Community, Economy, and Nation. Toronto: University of Toronto Press.

Belanger, A. (2005). Population Projections of Visible Minority Groups, Canada, Provinces and Regions, 2001-2017. Ottawa: Statistics Canada.

Bertossi, C., \& Duyvendak, J.W. (2012). National models of immigrant integration. The costs for comparative research. Comparative European Politics, 10 (3): 237-247.

Biles, J. (2008). Integration policies in English-speaking Canada. In: J. Biles, M. Burstein \& J. Frideres, (eds.).Immigration and Integration in Canada in the Twenty-first Century. Kingston: Queen's University, School of Policy Studies, 139-86.

Biles, J., E. Tolley, C. Andrew, V. Esses \& Burstein, M. (2011). Integration and inclusion in Ontario: The sleeping giant stirs. In:J. Biles, Burstein, M. \& Frideres, J. (eds.). Integration and Inclusion of Newcomers and Minorities Across Canada. Montreal/ Kingston: McGill-Queen's University Press, 195-246.

Bradford, N. (2005). Place-based Public Policy: Towards a New Urban and Community Agenda for Canada. Ottawa: Canadian Policy Research Networks.

Brubaker, R. (2001). The return of assimilation? Changing perspectives on immigration and its sequels in France, Germany, and the United States. Ethnic and Racial Studies, 24 (4), 531-48.

Caponio, T. \& Borkert, M. (eds.) (2010). The Local Dimension of Migration Policymaking. Amsterdam: Amsterdam University Press.

Carter, T. \& Amoyaw, B. (2011). Manitoba: The struggle to attract and retain immigrants. In: J. Biles, Burstein, M. \& Frideres, J. (eds.). Integration and Inclusion of Newcomers and Minorities Across Canada. Montreal and Kingston: McGill-Queen's University Press, 165-93.

Duyvendak, J.W. \& Scholten, P.W.A. (2011) Beyond the Dutch 'multicultural model: The coproduction of integration policy frames in the Netherlands. International Migration and Integration, $12(3), 331-348$.

Entzinger, H. \& Biezeveld, R. (2003). Benchmarking in Immigrant Integration. Rotterdam: European Research Centre on Migration and Ethnic Relations.

Falge, C., Ruzza, C. \& Schmidtke, O. (2012). Giving New Subjects a Voice. Political and Institutional Responses to Cultural Diversity in the Health Care System. Aldershot: Ashgate. 
FCM (2011). Starting on Solid Ground: The Municipal Role in Immigrant Settlement. http://www. fcm.ca/Documents/backgrounders/Starting_on_solid_ground_the_municipal_role_in_immigrant_settlement_Report_Overview_EN.pdf (accessed September 29, 2013).

Frideres, J.S. (2006). Cities and Immigrant Integration: The Future of Second-and Third-Tier Centres.OUrDiverse Cities. Metropolis: http://www.metropolis.net/pdfs/ODC_2_Frideres_e. pdf (accessed September 21, 2013).

Good, K. (2005). Patterns of politics in Canada's immigrant-receiving cities and suburbs: How immigrant settlement patterns shape the municipal role in multiculturalism policy. Policy Studies, 26 (3-4), 261-89.

Green, S. (2000). Beyond ethnoculturalism? German citizenship in the New Millennium. German Politics, 9, 105-24.

Hiebert, D. \& Sherrell, K. (2009). The Integration and Inclusion of Newcomers in British Columbia. Working Paper No. 2009-11, Vancouver: Metropolis British Columbia.

Hilber, D. \& Baraulina, T. (2012). Migration and development. A new policy paradigm in Germany? IMIS Beiträge, 40, 89-113.

Hooghe, L. \& Marks, G. (2001). European Integration and Multi-Level Governance. Boulder, CO: Rowman and Littlefield.

Ilgün, E.E. \& Jungk, S. (2001). Migration in NRW. Selbstorganisationen von Migranten und Migrantinnen. Landeszentrum für Zuwanderung (http://www.rk-essen.lvr.de/behandlungsangebote/ambulanzen/selbstorganisationenvonmigranteninnrw.pdf(accessed October 15, 2013).

Joppke, C. (2007). Beyond national models: Civic integration policies for immigrants in Western Europe. West European Politics, 30 (1), 1-22.

Korte, K.R. (2009). Wahlen in NRW: Kommunalwahl - Landtagswahl - Bundestagswahl - Europawahl. Schwalbach: Wochenschau-Verlag.

Koser, K. (2010). The impact of the global financial crisis on international migration. The Whitehead Journal of Diplomacy and International Relations, XI (1), 13-20.

Leo, C. \& August, M. (2009). The multilevel governance of immigration and settlement: Making deep federalism work. Canadian Journal of Political Science, 42 (2), 491-510.

Ley, D. (2007). Post multiculturalism? In: L. Hanley, B. Ruble \& A. Garland (eds.). Immigration and Integration in Urban Communities: Renegotiating the City. Washington, DC: Woodrow Wilson International Center Press, 177-97.

Li, P.S. (2012). Federal and provincial immigration arrangements in Canada: Policy changes and implications. In: Rodriguez-Garcia, D. (ed.). Managing Immigration and Diversity in Canada. A Transatlantic Dialogue in the New Age of Migration. Montreal/ Kingston: McGill-Queens University Press, 87-111.

Maytree Foundation (2013). Good Ideas from Successful Cities Municipal Leadership on Immigrant Integration. (http://www.citiesofmigration.ca/wp-content/uploads/2013/03/Municipal_Report_Canada.pdf; accessed October 1, 2013).)

Papademetriou, D. \& Terrazas, A. (2009). Immigrants and the Current Economic Crisis: Research Evidence, Policy Challenges, and Implications. Washington DC: MPI.

Parekh, B. (2006). Rethinking Multiculturalism. Cultural Diversity and Political Theory. Houndmills: Palgrave Macmillan.

Polese, M. \& Stren, R. (2000). The Social Sustainability of Cities: Diversity and the Management of Change. Toronto: University of Toronto Press.

Poppelaars, C., \& Scholten, P.W.A. (2008). Two worlds apart: The divergence of national and local immigrant integration policies in the Netherlands. Administration \& Society, 40 (4), 335-57.

Reese, I. (2011). Under Pressure - Atypical Asymmetry in Canadian Immigration Policy. Paper presented at the Canadian Political Science Association conference, Kitchener. 
Schmidtke, O. \& Zaslove, A. (2014a). Multilevel party politics of immigration in Germany and Italy. In E. Hepburn, ed., The Politics of Immigration in Multi-level States: Governance and Political Parties. Edinburgh: Edinburgh University Press (in press).

Schmidtke, O. \& Zaslove, A. (2014b). Why regions matter in immigrant integration policies: North-Rhine Westphalia and Emilia-Romagna in comparative perspective.Journal of Ethnic and Migration Studies (in press).

Schönwälder, K. (2013). Immigrant representation in Germany's regional states: The puzzle of uneven dynamics. West European Politics, 36 (3), 634-651.

Schönwälder, K. \& Kofri, C. (2010). Diversity in Germany's Political Life? Immigrants in City Councils. MMG Working Paper 10-17 (see http://www.mmg.mpg.de/de/publikationen/ all-publications/2010/:a accessed September 28, 2013).

Scholten, P.W.A. (2013). Agenda dynamics and the multi-level governance of intractable policy controversies: The case of migrant integration policies in the Netherlands. Policy Sciences, $46(3), 217-236$.

Seidle, F.L. (2010). The Canada-Ontario Immigration Agreement: Assessment and Options for Renewal. M.C.f.P. Innovation. Toronto: Mowat Centre for Policy Innovation.

Siemiatycki, M. (2011). Governing immigrant city: Immigrant political representation in Toronto. American Behavioral Scientist, 55 (9), 1214-34.

Siemiatycki, M. (2012). The place of immigrants: Citizenship, settlement, and socio-cultural integration in Canada. In: Rodriguez-Garcia, D. (ed.). Managing Immigration and Diversity in Canada. A Transatlantic Dialogue in the New Age of Migration. Montreal/ Kingston: McGillQueens University Press, 223-247.

Stasiulis, D., Hughes, C. \& Amery, Z. (2011). From government to multilevel governance of immigrant settlement in Ontario's city-regions. In: Tolley, E. \& Young, R. (eds.). Immigrant Settlement Policy in Canadian Municipalities. Montreal and Kingston: McGill-Queen's University Press, 73-147.

Tolley, E. (2011). Introduction: Who invited them to the party? Federal-municipal relations in immigrant policy. In: Tolley, E. \& Young, R. (eds.). Immigrant Settlement Policy in Canadian Municipalities. Montreal/ Kingston: McGill-Queen's University Press, 3-48.

Tossutti, L.S. (2012). Municipal roles in immigrant settlement, integration and cultural diversity. Canadian Journal of Political Science, 45 (3), 607-33.

Triadafilopoulos, T. (2011). Illiberal means to liberal ends? Understanding recent immigrant integration policies in Europe. Journal of Ethnic and Migration Studies, 37 (6), 861-80.

Triadafilopoulos, T. (2012). Becoming Multicultural:Immigration and the Politics of Membership in Canada and Germany. Vancouver: UBC Press.

Vasta, E. (2007). Accommodating Diversity: Why Current Critiques of Multiculturalism Miss the Point. COMPAS Working Paper Series 39. Oxford: University of Oxford, COMPAS.

Vertovec, S. (2006), The Emergence of Superdiversity in Britain, Centre on Migration, Policy and Society. Working Paper no 25, University of Oxford: COMPAS.

Vertovec, S. \& Wessendorf, S. (2010). The Multicultural Backlash: European Discourses, Policies and Practices. London: Routledge.

Wimmer, A. (2008). The making and unmaking of ethnic boundaries: A multilevel process theory. American Journal of Sociology, 113 (4), 970-1022.

Wimmer, A. \& Glick-Schiller, N. (2003). Methodological nationalism, the social sciences, and the study of migration: An essay in historical epistemology. International Migration Review, 37 (3), 576-610. 


\section{About the author}

Oliver Schmidtke, University of Victoria.

E-mail: ofs@uvic.ca

Oliver Schmidtke is a Professor in the Departments of Political Science and History at the University of Victoria where he also holds the Jean Monnet Chair in European History and Politics. He currently serves as the director of the Centre for Global Studies in Victoria. His research interests are in the fields of the political sociology and politics of migration, citizenship, nationalism, and the governance of migration and integration in Europe and Canada.

\section{(1) (1) $\odot$}

This is an Open Access article distributed under the terms of the Creative Commons Attribution License (http:// creativecommons.org/licenses/by/2.o), which permits unrestricted use, distribution, and reproduction in any medium, provided the original work is properly cited. 